\title{
nature
}

\section{All the President's yes-men?}

George W. Bush's administration stands accused of biasing the process by which the US government obtains scientific advice. There is a strong case to answer, but the situation is not as unusual as it might at first seem.

$\mathrm{T}$ he relationship between science and politics is never perfect, but critics charge that the current US administration has so politicized the provision of scientific advice that it could permanently undermine public trust.

Just last week, a storm of protest greeted the announcement that Jerry Thacker, an HIV-positive Christian activist who has referred to AIDS as a "gay plague", would be appointed to the Presidential Advisory Commission on HIV and AIDS. Three months before, a committee advising the Department of Health and Human Services on protecting volunteers in clinical trials was asked to consider whether embryos should be included within its remit (see Nature 420, 3-4; 2002) - a move that critics saw as part of a wider anti-abortion agenda.

The controversy extends to committees that review grant applications. Potential appointees to the panel advising the National Institute for Occupational Safety and Health, for instance, were asked their views on office safety standards - just one example, critics allege, of political considerations impinging on appointments that should depend on scientific merit. The fear is that scientists will refuse to serve on panels that are seen as rubber stamps for administration policies, undermining the quality of the advice given to government agencies and eroding public trust.

Some of the recent developments are disturbing. If the committee on human research subjects gets bogged down discussing abortion politics instead of how to protect patients in clinical trials, lives could be put at risk. Members of committees reviewing grant applications should be selected for their scientific expertise, not their political views.

But successive US administrations, both Republican and Demo- crat, have packed advisory committees with scientists and other experts who share their political outlook. This only becomes a major issue for the scientific community when the views in question jar with its majority opinion, or the politicization is blatant.

Those with long memories say that the present outcry is reminiscent of the furore inspired by Ronald Reagan's administration in the early 1980s, when it tried similar tactics with committees advising the Environmental Protection Agency — then seen as a thorn in the side of the administration's pro-business policies. This sorry episode alienated environmental scientists, but thankfully the administration eventually backed off and most of the damage was repaired.

There is some comfort to be gained from the checks and balances inherent to the system. The degree of transparency in the formulation of science-led policy in the United States has few parallels in the rest of the world. It is rare indeed for the public to be able to influence government decisions about who sits on the panels and what they discuss. And so far, public input seems to be having a positive effect — last week's storm led Thacker to withdraw from the HIV panel.

This does not mean that the critics should relax. They should look back at the actions of previous administrations to determine the extent to which the current moves represent a departure from accepted practice. The National Academies' Committee on Science, Engineering, and Public Policy is set to take up these questions at its next meeting on 19 February, providing a welcome and timely forum.

Scientists should fight undue attempts by the Bush administration to politicize the advisory process, and extend the same scrutiny to future administrations, whatever their political persuasion.

\section{Too quiet on the Eastern front}

\section{Change is needed before the nations poised to join the European Union can reap the full scientific benefits of membership.}

n May next year, the European Union (EU) will gain 75 million citizens at a single stroke, with the accession of ten new member countries, most of them in Central and Eastern Europe. Among those brought into Brussels' embrace will be some 250,000 researchers - a $15 \%$ rise in the EU's scientific workforce. But they won't come with bulging wallets: the eastwards expansion will increase the union's total spending on research by only $3.5 \%$.

Poland, home to more than half of the new EU citizens, provides a prominent example of the scientific weaknesses of the unions' budding members (see page 471). Although the Polish government is stressing that the country's future should not be one of cheap labour, it has done little to nurture a knowledge-based economy. Research spending stagnates at a shameful $0.34 \%$ of public expenditure.

But money is only part of the problem. Poland, like many of its neighbours, has too many scientists who aren't internationally competitive, and who cling to the certainties of the socialist era. Unfortunately, many of them sit in senior positions and intend to stay there, which sends genuine achievers to seek opportunities abroad.

Streamlining the overstaffed research system, and letting in the fresh air of competition, is an urgent necessity. The talent exists, and several research groups are finding niches where Poland can successfully contribute to state-of-the-art research.

Much now depends on another ray of hope: science minister Michal Kleiber. A respected physicist and engineer who joined the government last year, Kleiber has already convinced his colleagues to elevate the State Committee for Scientific Research to a fully fledged ministry. That should give him more clout to push through reforms, but the task remains devilishly hard.

The old guard is bound to fight efforts to concentrate funding into groups that can compete on the European stage, and to close labs that just aren't good enough. But Kleiber's political peers should back him through any short-term unpopularity. Poland will change under EU membership, and some of those changes will hurt. If its research base can be successfully reformed, there is much to be gained in terms of collaboration with Western European scientists - not to mention research grants from Brussels.

The same issues face many of other nations queuing up to join the EU. It would be satisfying to see the largest of the new countries leading the way towards the promised land of European scientific integration, rather than dragging its feet. 